\title{
Effects of Recombinant Human Erythropoietin on Fetal and Adult Hemoglobin in Preterm Infants
}

\author{
ANNE GRETE BECHENSTEEN, HARALD E. REFSUM, SVERRE HALVORSEN, PER HÅGÅ, AND \\ KNUT LIEST $\varnothing \mathrm{L}$ \\ Departments of Pediatrics and Pathology [A.G.B.], Clinical Physiology [H.E.R.], and Pediatrics \\ [S.H., P.H.], Ullevål University Hospital, Oslo, and Department of Informatics [K.L.], University of Oslo, \\ Oslo, Norway
}

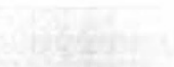
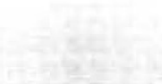

In the present study we assess the effect of recombinant human erythropoietin (r-HuEpo) upon levels of fetal $\mathrm{Hb}(\mathrm{HbF})$ and adult $\mathrm{Hb}(\mathrm{HbA})$ in preterm infants. Twenty-eight "healthy," appropriate for gestational age infants with birth weights 900$1400 \mathrm{~g}$ entered the study at $3 \mathrm{wk}$ of age. Fourteen infants were randomized to receive r-HuEpo, and 14 infants served as controls. Four controls and six r-HuEpo treated infants had been transfused before study start, whereas four control infants were transfused in the course of the study. The untransfused infants showed a high $\mathrm{HbF} / \mathrm{Hb}$ ratio during the study with only a weak tendency to decline toward the expected time of delivery. The total $\mathrm{Hb}$ mass increased $(p<0.05)$ more in the r-HuEpo-treated infants than in the untreated, whereas the rise in $\mathrm{HbF}$ mass was similar in the two groups. After each transfusion, the $\mathrm{HbF} / \mathrm{Hb}$
\end{abstract}

Before $35 \mathrm{wk}$ of gestation more than $90 \%$ of the $\mathrm{Hb}$ in the blood is fetal. Thereafter, the $\mathrm{HbF} / \mathrm{Hb}$ ratio decreases slowly, and amounts to about $80 \%$ in full-term infants at birth (1). The mechanisms regulating the switch from synthesis of fetal to $\mathrm{HbA}$ as well as the timing of this switch have remained controversial (2). Some studies conclude that environmental factors, e.g. birth, seem to be accompanied by a gradual decrease in the synthesis of $\mathrm{HbF}(2-4)$. Studies in preterm infants $(5,6)$ and experimental animal studies $(7)$ indicate that the switch is related to the postconceptional age, and that a "developmental clock" rather than environmental factors controls the Hb switching. The time of the switching has, however, not been clarified.

Recent studies have shown that r-HuEpo treatment increases the postnatal red cell production in very low birth weight infants $(8-13)$. This increased red cell production has been reported to favor $\mathrm{HbF}$ production $(8,12,13)$. It is, however, still an open question whether, or in which way, the r-HuEpo-

Received April 21, 1994; accepted May 22, 1995

Correspondence: Anne Grete Bechensteen, Department of Pediatrics, Ullevål University Hospital, 0407 Oslo, Norway.

A.G.B. is the recipient of a research fellowship from the Norwegian Cancer Society and Ullevål Hospital Research Fund. ratio reverted gradually to the ratio expected at the infant's postconceptional age. There was no difference in the production rate of $\mathrm{HbF}$ between $\mathrm{r}-\mathrm{HuEpo-treated} \mathrm{infants} \mathrm{and} \mathrm{controls.} \mathrm{The}$ present data indicate that the $\mathrm{HbF} / \mathrm{HbA}$ ratio in preterm infants is subject to the same programmed mechanisms which govern intrauterine erythropoiesis until term and that exogenous rHuEpo does not influence this pattern significantly. (Pediatr Res 38: 729-732, 1995)

Abbreviations
r-HuEpo, recombinant human erythropoietin
HbF, fetal $\mathrm{Hb}$
$\mathrm{HbA}$, adult $\mathrm{Hb}$

induced rise in erythropoiesis influences the $\mathrm{HbF} / \mathrm{Hb}$ ratio, and further studies addressing this problem have been called for (14).

The purpose of this study was to estimate and compare the net changes in $\mathrm{HbF}$ and $\mathrm{HbA}$ during the postnatal period in very low birth weight infants, with and without r-HuEpo treatment.

\section{METHODS}

The data were collected from the 28 preterm infants who completed a previously described randomized investigation of the influence of r-HuEpo treatment on the erythropoiesis during the anemia of prematurity (11). The infants in this study were all appropriate for gestational age with birth weight between 900 and $1400 \mathrm{~g}$, healthy and without ongoing infection. None needed artificial ventilation and fraction of inspired air $\left(\mathrm{FiO}_{2}\right)$ was less than $40 \%$ oxygen. The study period lasted from age $3 \mathrm{wk}$ to age $8 \mathrm{wk}$ with an additional assessment at 16 wk. They were all fed human milk (mother's milk or bank milk) fortified with human milk protein to yield a daily protein intake of about $3 \mathrm{~g} / \mathrm{kg}$. Eighteen milligrams of iron were given daily from the start of the study and doubled if serum iron fell below $16.0 \mu \mathrm{mol} / \mathrm{L}$. Fourteen infants were randomized to 
receive $100 \mathrm{U} / \mathrm{kg}$ r-HuEpo (Eprex, Cilag, $2000 \mathrm{U} / \mathrm{mL}$ ) s.c. thrice weekly from wk 3 to wk 7, whereas 14 infants served as controls. Blood was sampled weekly in the amount of about 1.2 $\mathrm{mL} /$ week.

Six of 14 infants in the r-HuEpo group and 8 of 14 in the control group received $\mathrm{HbA}$ blood transfusions, either before or during the period of observation ("transfusion group"). These infants were slightly younger, with lower body weight and $\mathrm{Hb}$ concentration than the nontransfused infants. There were no differences with respect to gestational age, birth weight, weight gain, or initial $\mathrm{Hb}$ concentration between the r-HuEpo treated infants and the controls (Table 1).

The transfused blood consisted of $\mathrm{HbA}$ red blood cells from freshly tapped $\mathrm{O}$ blood, suspended in plasma from $\mathrm{AB}$ blood to give a hematocrit of $60 \%$.

Blood for determination of $\mathrm{HbF}$ was collected at postnatal age $3,5,7,8$, and $16 \mathrm{wk}$ (some infants also at wk 4 and 6 ). The percentage $\mathrm{HbF} / \mathrm{Hb}(\mathrm{HbF} \%)$ was determined with a modification of the spectrophotometric method of Fogh-Andersen et al. (15) using a Radiometer OSM3 Hemoximeter. To minimize the the blood sampling the analysis was performed in $100-\mu \mathrm{L}$ samples of packed heparinized red blood cells, i.e. the rest after removing plasma for other analyses, suspended in $100 \mu \mathrm{L}$ of $0.9 \% \mathrm{NaCl}$. In a pilot study on 11 individual full-term infants at birth, mean $\mathrm{HbF} \%$ was 79.8 (range: 71-89). In seven samples taken from one pool of newborn infants $\mathrm{HbF} \%$ was 81.1 (79-82). Dilution of a blood sample with $\mathrm{HbF} \%$ of 89 with $\mathrm{HbA}$ blood to $1 / 2,1 / 4$, and $1 / 8$ of the original gave $\mathrm{HbF} \%$ values of 46,22 , and 12 , respectively.

$\mathrm{Hb}$ mass was calculated as $\mathrm{Hb}(\mathrm{g} / \mathrm{dL}) \times$ actual body weight (g) $\times 0.08$, whereas $\mathrm{HbF}$ and $\mathrm{HbA}$ mass were calculated as $\mathrm{Hb}$ mass $\times \mathrm{HbF} \%$ and $\mathrm{Hb}$ mass $\times(100-\mathrm{HbF}) \%$, respectively.

Statistics. Test of group differences were based on $t$ tests or regression analyses. Initial values (at age $3 \mathrm{wk}$ ) were, when appropriate, used as covariates to compensate for differences in initial values and to increase the power of the tests. When describing the $\mathrm{HbF} \%$ versus time relationship, we used a smoothing spline constructed by the JPM statistical system (smoothness parameter $=100$ ).

\section{RESULTS}

Figure 1 shows the relationships between $\mathrm{HbF} \%$ and postconceptional age in nontransfused control and r-HuEpotreated infants. $\mathrm{HbF} \%$ remained high until the age of $38-40$ wk in both groups. Thereafter a marked decline in $\mathrm{HbF} \%$ was

Table 1. Some characteristics of nontransfused infants

\begin{tabular}{lcc}
\hline & Controls & r-HuEpo \\
\hline No. of infants & 6 & 8 \\
Gestational age (wk) & $30.7(0.9)$ & $30.4(0.6)$ \\
Birth weight (g) & $1280(42)$ & $1297(29)$ \\
Weight (g), wk 3 & $1552(54)$ & $1503(30)$ \\
Weight (g), wk 8 & $2693(69)$ & $2479(62)$ \\
Initial Hb (g/dL), wk 3 & $13.6(0.8)$ & $13.2(0.6)$ \\
HbF\%, wk 3 & $88.5(1.8)$ & $91.3(1.6)$ \\
\hline
\end{tabular}

Data are presented as mean (SEM). There were no differences between the treatment groups ( $\mathrm{r}-\mathrm{HuEpo}$ and controls).

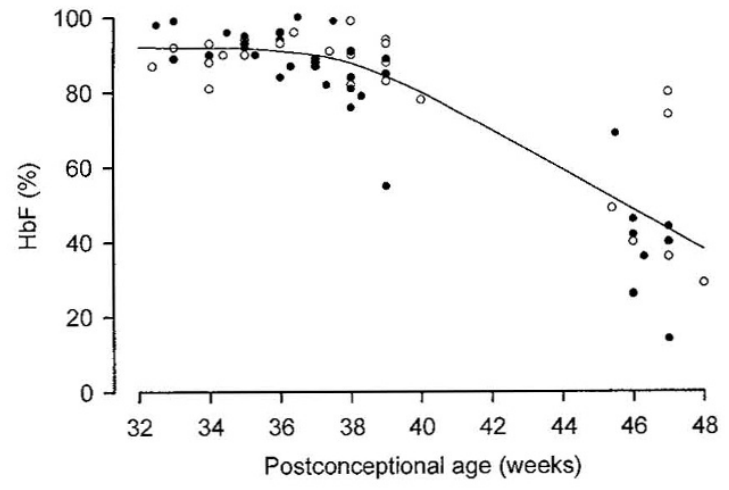

Figure 1. HbF levels (\%) in individual, nontransfused infants $v s$ postconceptional age. Infants treated with $\mathrm{r}-\mathrm{HuEpo}(\bullet)$, controls $(\bigcirc)$. There were no statistically significant differences between the two groups. The line represents the combined spline curve for both treatment groups (see text).

observed. There was no statistically significant difference in $\mathrm{HbF} \%$ between the controls and the r-HuEpo-treated infants.

Figure 2 shows the changes in $\mathrm{HbF}$ and $\mathrm{HbA}$ mass in the nontransfused infants. During r-HuEpo treatment, from wk 3 to wk 7 postnatally, the total $\mathrm{Hb}$ mass showed a marked rise in the $\mathrm{r}$-HuEpo-treated infants $(p<0.01)$, but only a minor increase was found in the control infants. For both groups the major part of the rise in total $\mathrm{Hb}$ mass during wk 3 to 8 was accounted for by an increase in $\mathrm{HbF}$ mass, $4 \mathrm{~g}$ in the controls and $5 \mathrm{~g}$ in the $\mathrm{r}$-HuEpo-treated infants. The absolute increase in $\mathrm{HbA}$ mass was smaller, $3 \mathrm{~g}$ in the r-HuEpo-treated infants and $1 \mathrm{~g}$ in the controls. From wk 3 to wk 8 the production of $\mathrm{HbA}$ was slightly higher in the r-HuEpo-treated infants than in the controls, but this difference between the groups did not reach statistical significance. From the 8th to the 16th wk the $\mathrm{HbF}$ mass remained essentially unchanged in both groups, and the further marked rise in $\mathrm{Hb}$ mass was due to a rise in $\mathrm{HbA}$ mass only.

After the depression of $\mathrm{HbF} \%$ caused by $\mathrm{HbA}$ transfusion, there was a rise in $\mathrm{HbF} \%$ toward the level observed in the nontransfused infants, both in the r-HuEpo-treated and control infants. Figure 3 illustrates the changes in $\mathrm{HbF} \%$ following transfusions for 5 of the 14 transfused infants, all with $\mathrm{HbF}$ measurements determined within $1 \mathrm{wk}$ after the last blood transfusion.

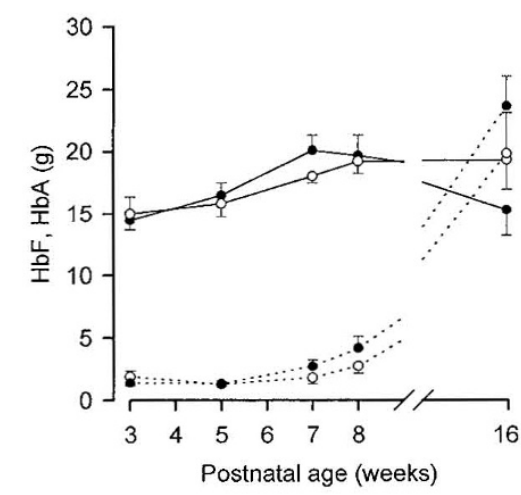

Figure 2. Mean values (SEM) of $\mathrm{HbF}(\longrightarrow$ ) and $\mathrm{HbA}(\cdot \cdots \cdot)$ masses vs postnatal age for infants not being transfused before or during the study. r-HuEpo-treated infants $(\bullet)$; controls $(\bigcirc)$. 


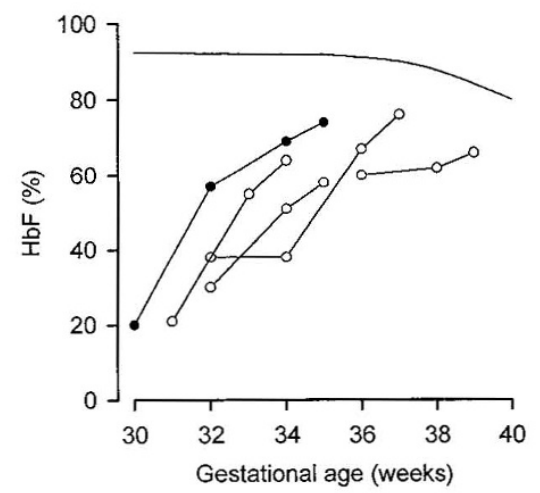

Figure 3. $\mathrm{HbF}(\%) v s$ postconceptional age in individual preterm infants transfused with red blod cells within $1 \mathrm{wk}$ before a HbF measurement. This and the subsequent measurements until age $8 \mathrm{wk}$ are displayed. (r-HuEpo-treated $(\bullet)$ and control infants $(\bigcirc)$.) The line represents the spline curve for $\mathrm{HbF}$ development in untransfused preterm infants (see Fig. 1).

\section{DISCUSSION}

Previous studies in preterm infants indicate that the switch from $\mathrm{HbF}$ to $\mathrm{HbA}$ synthesis is related to postconceptional age rather than to time of birth $(5,6)$, although the mechanisms controlling this switch are not fully understood $(2,7)$. Although some studies report a gradual fall in $\mathrm{HbF}$ levels in premature infants with increasing gestational age $(5,6,16,17)$, the present results suggest a stable level of $\mathrm{HbF} \%$ until close to the expected date of delivery (wk 38-40 postconceptionally). In these nontransfused infants born at a mean postconceptional age of $30.5 \mathrm{wk}, \mathrm{HbF}$ remained high at about $90 \%$ of total $\mathrm{Hb}$ until wk 38-40. The net rise in HbF mass during this period was greater than that of $\mathrm{HbA}$ mass. During these weeks the active erythropoiesis (11) produces predominantly fetal $\mathrm{Hb}$. The postnatal continuation of $\mathrm{HbF}$ production is also clearly demonstrated in the slightly younger, more anemic infants with several $\mathrm{HbA}$ blood transfusions before or during the study. Reduced $\mathrm{HbF} \%$ levels are initially observed, and then a net rise in $\mathrm{HbF}$ takes place (Fig. 3). The present results support the work by Brown et al. (18) also suggesting continued $\mathrm{HbF}$ production postnatally in preterm infants.

In experimental animal studies $(19,20)$ and in sickle cell diseases (21), Epo stimulation induces increased $\mathrm{HbF}$ production. Recent studies of the effect of r-HuEpo treatment on erythropoiesis in very low birth weight infants apparently indicate that $\mathrm{r}-\mathrm{HuEpo}$ treatment favors production of $\mathrm{HbF}$ at the cost of $\mathrm{HbA}(8,12,13)$. This is in contrast to our current findings in the nontransfused infants where r-HuEpo had a very small influence on the $\mathrm{HbF} / \mathrm{HbA}$ ratio.

In the study of Emmerson et al. (12) $\mathrm{Hb}$ was kept at a certain level either by $\mathrm{r}-\mathrm{HuEpo}$ treatment or by transfusions. A reduction in the amount of $\mathrm{HbA}$ blood transfused by r-HuEpo must necessarily have led to higher $\mathrm{HbF}$ in the r-HuEpo group than in the controls. Likewise, in the study by Shannon et al. (10) previously transfused infants with initially low $\mathrm{HbF}$ and no further transfusions during the r-HuEpo treatment were bound to have a rise in $\mathrm{HbF}$. This finding is consistent with our observation of a strong tendency to re-establish a high $\mathrm{HbF} \%$ after blood transfusions. In the work by Bard and Widness (13) the increased $\mathrm{HbF}$ synthesis observed in the r-HuEpo-treated infants was due to a skew age distribution: the r-HuEpo treated infants were slightly younger with a synthesis of $\mathrm{HbF}$ lasting longer than seen in the placebo treated infants (Widness $\mathbf{J}$, personal communication).

In the present study the transfused control infants had the same rapid increase in $\mathrm{HbF}$ as had the infants treated with r-HuEpo (Fig. 3). There was no evidence to indicate that $\mathrm{r}-\mathrm{HuEpo}$ influenced the relationship between $\mathrm{HbF}$ and $\mathrm{HbA}$ in these transfused infants.

The prolonged maintenance of a high $\mathrm{HbF}$ level and the consequent delay in shift of the $\mathrm{Hb} \mathrm{O}_{2}$ dissociation to the right is in theory unfavorable for $\mathrm{O}_{2}$ delivery to the tissues in anemic infants. Thus, in an anemic preterm infant a given therapeutic rise in $\mathrm{Hb}$ would theoretically produce a greater quantity of available $\mathrm{O}_{2}$ when the rise in $\mathrm{Hb}$ is caused by $\mathrm{HbA}$ blood transfusion than if it is due to the infant's own production, spontaneous or rHuEpo-induced (22). However, adult blood has clearly other disadvantages (e.g. blood-borne infections, human immunodeficiency virus, cytomegalovirus, hepatitis) (23) that make red cell transfusions undesirable for preterm infants.

In summary, the present data indicate that at least up to the expected date of delivery the $\mathrm{HbF} / \mathrm{Hb}$ ratio in preterm infants is subject to the same programmed mechanisms which govern the intrauterine erythropoiesis until term. Exogenous r-HuEpo influences this pattern only marginally.

Acknowledgments. The authors thank Lea Bak, Department of Clinical Physiology, for skillful technical work. We also thank Cilag for financial support and provision of Eprex.

\section{REFERENCES}

1. Galacteros F, Guilloud-Bataille M, Feingold J 1991 Sex, gestational age and weight dependency of adult hemoglobin concentration in normal newborns. Blood 78:11211124

2. Mahoney JJ, Wong RJ, Vreman HJ, Stevenson DK 1991 Fetal hemoglobin of transfused neonates and spectrophotometric measurements of oxyhemoglobin and carboxyhemoglobin. J Clin Monit 7:154-160

3. Colombo B, Kim B, Perez Atencio R, Molina C, Terrenato L 1976 The pattern of fetal haemoglobin disappearance after birth. Br J Haematol 32:79-87

4. Moriyama I, Hino K, Ninomiya Y, Nabuchi K, Kato Y, Tsuji Y, Ichijo M 1989 The problem of hemoglobin switching in premature infants and IUGR infants. Asia Oceania J Obstet Gynaecol 15:87-92

5. Bard H 1973 Postnatal fetal and adult hemoglobin synthesis in early preterm newborn infants. J Clin Invest 52:1789-1795

6. Phillips HM, Holland BM, Jones JG, Abdel-moiz AL, Turner TL, Wardrop CAJ 1988 Definitive estimate of rate of hemoglobin switching: measurement of percent hemoglobin F in neonatal reticulocytes. Pediatr Res 23:595-597

7. Wood WG, Bunch C, Kelly S, Gunn Y, Breckon G 1985 Control of haemoglobin switching by a developmental clock? Nature 313:320-323

8. Halperin DS, Wacker P, Lacourt G, Felix M, Babel JF, Aapro M, Wyss M 1990 Effects of recombinant human erythropoietin in infants with the anemia of prematurity: a pilot study. J Pediatr 116:779-786

9. Shannon KM, Mentzer WC, Abels RI, Freeman P, Newton N, Thompson D, Sniderman S, Ballard R, Phibbs RH 1991 Recombinant human erythropoietin in the anemia of prematurity: results of a placebo-controlled pilot study. J Pediatr 118:949955

10. Shannon MK, Mentzer WC, Abels RI, Wertz M, Thayer-Moriyama J, Li WY, Thompson D, Decelle S, Phibbs RH 1992 Enhancement of erythropoiesis by recombinant human erythropoietin in low birth weight infants: a pilot study. J Pediatr 120:586-592

11. Bechensteen AG, Hågå $P$, Halvorsen $S$, Whitelaw A, Liestøl K, Lindemann $R$, Grøgaard J, Hellebostad M, Saugstad OD, Grønn M, Daae L, Refsum H, Sundal E 1993 Erythropoietin, protein, and iron supplementation and the prevention of anaemia of prematurity. Arch Dis Child 69:19-23

12. Emmerson AJB, Coles HJ, Stern CMM, Pearson TC 1993 Double blind trial of 
recombinant human erythropoietin in preterm infants. Arch Dis Child 68:291-296

13. Bard H, Widness J 1994 Recombinant Human Erythropoietin (EPO) delays the switchover from fetal $(\mathrm{HbF})$ to adult $(\mathrm{HbA})$ hemoglobin synthesis in preterm infants. Pediatr Res 35:157A(abstr)

14. Strauss RG (ed) 1994 Erythropoietin and neonatal anemia. N Engl J Med 330:12271228

15. Fogh-Andersen N, Siggaard-Andersen O, Lundsgaard FC, Wimberley PD 1987 Spectrophotometric determination of hemoglobin pigments in neonatal blood. Clin Chim Acta 166:291-296

16. Warner A, Jang R 1989 Hemoglobin F: relationship to maturity measures in the neonate. Ann Clin Lab Sci 19:122-127

17. Bard H 1992 Hypoxemia and increased fetal hemoglobin synthesis during the perinatal period. Semin Perinatol 16:191-195

18. Brown MS, Phipps RH, Dallmann PR 1985 Postnatal changes in fetal hemoglobin, oxygen affinity and 2,3-diphosphoglycerate in previously transfused preterm infants. Biol Neonate 48:70-76

19. Al-Khatti A, Veith RW, Papayannopoulou T, Fritsch EF, Goldwasser E, Stamatoyannopoulos G 1987 Stimulation of fetal hemoglobin synthesis by erythropoietin in baboons. N Engl J Med 317:415-420

20. Blau CA, Constantoulakis P, Al-Khatti A, Spadaccino E, Goldwasser E, Papayannopoulou T, Stamatoyannopoulos G 1993 Fetal hemoglobin in acute and chronic states of erythroid expansion. Blood 81:227-233

21. Nagel RL, Vichinsky E, Shah M, Johnson R, Spadacino E, Fabry ME, Mangahas L Abel R, Stamatoyannopoulos G 1993 F reticulocyte response in sickle cell anemia treated with recombinant human erythropoietin: a double-blind study. Blood 81:9-14

22. Stockman JA, Garcia JF, Oski FA 1977 The anemia of prematurity. Factors governing the erythropoietin response. N Engl J Med 296:647-650

23. Strauss RG 1991 Transfusion therapy in neonates. Am J Dis Child 145:904-911 